THURSDAY, APRIL 5, 1888.

THE FORESTRY SCHOOL AT COOPER'S HILL.

THE Forestry School at Cooper's Hill is intended in the first place for the education of a certain number annually of young officers for the Indian Forest Department. The arrangements are, nevertheless, of such a kind that private students are admitted to the forestry course, in as far as space is available, and on condition that they conform to the rules.

It is in many ways advantageous that the Forestry School is attached to the Royal Indian Engineering College at Cooper's Hill. Although the course for forest students is necessarily different from that designed for engineering students, there are several subjects to be studied in common, and consequently the present arrangements admit of the forest students obtaining their training in surveying, descriptive engineering, and mathematics, for instance, in the excellent courses provided by the wellknown Professors in the Engineering College.

The Forestry School itself consists of a block of buildings attached to the Royal Indian Engineering College, on the brow of Cooper's Hill, near Staines, and looking north over Runnymede and the Valley of the Thames. It is within a convenient distance from London, the traveller arriving at Egham (the nearest station on the London and South-Western Railway) in from forty-five to sixty minutes from Waterloo. Windsor Great Park is within a mile of the beautiful and spacious grounds in which the College stands, and the fine trees of all kinds to be met with in the neighbourhood give to the situation much that is desirable for a centre for the teaching of forest botany, and several parts can be made use of to a certain extent for illustrating subjects in forestry proper.

The building of the Forest School itself consists of large and small class-rooms, a museum, and the welldesigned and appointed botanical laboratory. In this block the students pursue their main studies-botany, forestry, and entomology. Their other studies-engineering, surveying, mathematics, geometrical and freehand drawing, physics, geology, and one or two other subjects to be referred to presently - are pursued under the direction of the various Professors in the class-rooms and laboratories of the Royal Indian Engineering College, to which the Forestry School is attached.

The forest museum is a convenient, well-lighted room, rapidly filling with useful collections of specimens illustrating the chief departments of forestry. Among the most valuable and conspicuous objects in this splendid collection may be mentioned the series of European and Indian timbers, which are so disposed that the student has ready access to them, while the Professors are able to refer to them in lecturing, and thus to make the teaching, in the best sense of the word, practical. Then there is a remarkably complete and interesting collection of implements used in forestry, and there are models of timberslides, apparatus for catching timber, and other forest works, also so disposed that every student can handle and examine them and learn their uses with facility. Another valuable feature in this museum is the series of economic products of Indian plants. This is of course not complete, VOL XXXVII.-No. 962. but the greatest credit is due to all concerned for bringing together for such useful purposes so many instructive specimens of fibres, seeds, barks, fruits, food-materials, \&c., from the chief representative Indian plants; and when it is remembered that the Forestry School is so young, in this country (it was started in September 1885), it is the more praiseworthy that the authorities have made such good use of their opportunities and time. The collections must no doubt receive numerous additions as time passes, for it is well known that a museum takes many years to bring within measurable distance of completeness, but the Cooper's Hill museum is already fairly filled, the nucleus of the collections having been derived from the late Indo-Colonial Exhibition, and from the Royal Gardens, Kew. It would require too much space to enumerate the remaining interesting features of these instructive series of forest objects: specimens of timber showing the changes due to abnormal growths, the healing of wounds, the various injuries produced by unsuitable environment or by the attacks of insects and other living organisms, and last, but by no means least, a unique collection showing the ravages of those fungi which injure timber-trees, collected by Prof. Robert Hartig: of Munich, and presented to the School, and a collection of the more injurious forest insects, presented by Herr Oberforstrath Judeich, of Tharand. There is also a small herbarium, of a particularly interesting character, containing an excellent series of Conifers and other trees.

The botanical laboratory has just been completed, and is, without doubt, one of the best designed small laboratories, for its purpose, that we have seen. It consists of an oblong room running east and west, and lighted from the north and east by windows arranged conveniently for work with the microscope. There are also tables and apparatus for experimental demonstrations in vegetable physiology ; provision will exist for cultivating seedlings and plants at constant temperatures, for measuring growth, and for exhibiting the influence of light, gravitation, \&c., on the growth of plants; and arrangements for showing the quantities of water given off from transpiring leaves, for developing plants in water-cultures, \&c. The students are supplied with microscopes, reagents, and accessories, and are taught to familiarize themselves thoroughly with all modern appliances bearing practically on their studies.

The above-mentioned block of buildings also includes one small and one larger lecture-room, which are provided with necessary teaching appliances. The series of botanical diagrams especially are remarkably good, and in fact many of them are unique, being the private property of the Professor of Botany, and drawn and coloured by himself. Another feature which must not be overlooked is the projected botanic garden. This will consist of a series of seed-beds, \&c., illustrating the raising of forest trees, and of beds of plants chosen from the most important natural families, in order that the students may familiarize themselves on the spot with their chief characteristics. This botanic garden is now in process of being laid out, and it will be ready for the use of students in a short time.

The courses of studies followed by the forest students are admirably adapted to the wants of practical men 
whose lives will be largely spent in the creating, planting, preserving, and using of forest and other trees. Obviously, such a course must comprise several branches of teaching, the one thing common to all being that they bear upon the practical needs of the future forester. That the same training applies to a planter or estate-manager needs no remark, and portions of the course would be suited for others engaged in work in woodlands, and in the colonies, \&c. The full course, as at present set forth in the syllabus of studies, is as follows.

The student begins work in September, and attends lectures regularly during two academical years. In engineering, he is taught the principles of roadmaking, and the building of forest bridges and other structures; he is also instructed in the practice and theory of surveying under the care of the Professor of Surveying. In his first year he studies for two terms under the Instructor in Geometrical Drawing, and in his second year receives lessons in the keeping of accounts. To these subjects may be added freehand drawing, and a modern language. In addition to these more technical subjects, the student attends certain short courses in mathematics and in applied mathematics, under the Professors of these sciences; he also studies physicsin lectures, as well as in the laboratory-entomology, and geology: A short course on organic chemistry is now being commenced.

The rest of his work consists in the special training as a forester, and it may safely be stated that there is no other centre in the Empire where so thorough and excellently designed a curriculum for a forester or planter can be obtained. The two subjects of forestry and botany are under the care of separate Professors. Dr. Schlich lectures on forestry, dividing his subject as follows :- In the first year he deals with the various soils, climates, and the regulating effects of forests on these; sylviculture, artificial and natural woods; the tending, thinning, pruning, \&c. ; the protection of forests against man and other animals, and especially insects, and against injurious plants, climatic influences, \&c. During the second year the student is instructed in the utilization of forests; the technical qualities of woods; the felling, shaping, transportation, \&c., of timber ; the utilization of minor forest produce; the preservation of wood; sawmills; charcoal, \&c. He then passes to the study of working plans, and especially the arrangement of cuttings; surveying and mapping forests ; measurement and determination of ages of trees and forests; and the methods of regulating the yield of forests. The final course of lectures is on forest law. In addition to the lectures, the students also make occasional excursions, under the direction of Dr. Schlich ; the neighbourhood of Windsor Forest facilitating this important object, and enabling the Professor of Forestry to make his teaching thoroughly practical.

In botany, under the management of Prof. Marshall Ward, the students are instructed by means of lectures, and practical work in the laboratory and in the fields and woods of the neighbourhood. The course in botany is designed to train foresters, not technical botanists : its aim is throughout practical, and directed to teaching the students exact and thorough knowledge of the life-phenomena of the trees and plants which it will be their duty to rear, and take care of, and utilize in the future. Commencing with a short course of thoroughly practical instruction in the elementary biology of plants selected as illustrative types of the vegetable kingdom, the young student is taught the use of the microscope and how to apply it practically in examining the tissues of plants. He is then instructe 1 in the organography and anatomy of plants, learning (not only in lectures, but also in the laboratory and in the field) what the organs of plants are, and what they do; so that roots, stems, leaves, buds, bulbs, tubers, tendrils, thorns, \&c., become to him not mere abstractions, but objects on which his attention will be continually fixed as active parts of plants. The study of cells and their contents, of epidermis and stomata, of vascular bundles and other tissues - of wood, bark, cambium, and so forth-is carried on thoroughly, not only that the forester may know the principles by which to classify and recognize timbers and forest products, and learn their uses, but also that he may understand what these various parts of the plants do in nature: how heart-wood is formed, how the timber grows and may be improved, how wounds may be healed over, how the roots take up substances from the soil, and how the plant makes use of them, and so forth. The student concludes his first year's study in botany (in the early summer) by familiarizing himself with the names and systematic position of the plants in the neighbouring fields and woods, especial attention being paid to the important trees and shrubs, and their relations to the forest flora of India.

During his second year, the student is instructed in the physiology of plants-how they feed, respire, and chemically change substances in their interior; how they grow, and are affected by light, gravitation, temperature moisture, \&c. ; how they are reproduced, hybridized, and so on; the effects of various agents in the production of wood, in influencing the fertility, and so forth. The course is completed by the study of the diseases of plants, and especially of timbers, and how their effects may be minimized or healed.

As special features of the greatest importance, it should be mentioned that the senior students pay periodic visits to the magnificent gardens, museums, and plant-houses at Kew, under the direction of Prof. Marshall Ward, in order that their knowledge of the important economic plants and their products shall be real. They see the plants growing, learn to familiarize themselves with their peculiarities and habits and uses, and are thus not strangers to them when they land in India. Secondly, the young foresters are taken abroad, and taught what life in the forest really is. At the completion of their first year's studies, they accompany the Professor of Forestry to Scotland, or to the New Forest, or to the Forest of Dean, as may be decided for the year; and at the end of their second year they are taken to the Continent for three or four months' practical work in Germany and France, to examine the systems pursued in the large and more systematically managed forests of those countries, and thus to study the art of forestry in practice under conditions more resembling those met with in the huge and valuable forests of India.

During the summer of I887, for instance, the young officers who are now in India were taken to Bavaria, under the direction of Dr. Schlich, accompanied by Prof. Marshall Ward and Mr. Gamble. They visited the 
magnificent museum and laboratories of the Forestry School at Munich, the Forest of Freising, the willow nurseries and plantations at Oberberghausen, the spruce forests at Hohenaschau, and the timber depot at Traunstein. They then proceeded to the Austrian forests of the Salzkammergut ; and later to the Forest School and school forests at Nancy, the cork oaks and pine forests in the Esterel, and the Pinus maritima forests on the west coast of France, used for the preparation of turpentine as well as for timber.

With this practical tour, the training of the young forester in Europe stops, and he departs for India to assume the new duties and large responsibilities of his life as a forest officer under the Imperial Government.

\section{THE BALTIC AMBER COAST IN PREHISTORIC TIMES.}

Die prähistorischen Denkmäler der Provinz Westpreussen und der angrenzenden Gebiete. Von Dr. A. Lissauer. (Leipzig: Engelmann, I887.)

THE prehistoric antiquities of that part of the Baltic coast that lies about the mouth of the Vistula have something more than a local interest. The old Prussian shore - the land of the Æstii of Tacitus and Cassiodorus, of the Estas of King Alfred-had already in very early times a European importance in its connection with the widely ramifying amber commerce of antiquity, of which this was in historic times the richest field of production. The present work by Dr. Lissauer, the President and founder of the Anthropological Section of the Natural History Society of Danzig, is peculiarly welcome as giving in a thoroughly scientific form a summary of the results of the archæological discoveries made in recent years relating to the prehistoric period in the province of West Prussia and its border districts. The author has divided the work into several sections, corresponding to the Neolithic, Hallstatt, and the successive Iron Age periods, and has accompanied each with an excellent synoptic list of the various individual finds.

Of the earlier Palæolithic Age there are, of course, no remains in this Baltic tract, which was still covered with an ice-sheet at a time when primæval man had already begun to tenant the caves of Cracow. As the ice retreated there was formed the great glacier stream at present represented by the Vistula, but which then prolonged its course to the west, and, joining with the Elbe, poured its waters into the German Ocean. The physical event which in this region dominates all the succeeding history is the breaking through of the Vistula at Fordon, near Bromberg, and the formation of the new channel by which it poured itself henceforth into the Gulf of Danzig; and this, geologically speaking, was a comparatively recent consummation. The author has reproduced an elaborate calculation of Jentzsch, based on the formation of the delta and the average amount of sediment conveyed by the waters of the Vistula, according to which the breaking through of that river to the north must have taken place approximately about 3000 B.C. That the Neolithic immigration into the Old Prussian land from the south must have taken place at an early period is seen from the local distribution of these remains, which tends to show that the ice and snow still lingered on the higher parts of the country. On the other hand, from the fact that Neolithic settlements are peculiarly abundant in the old bed of the Vistula itself, Dr. Lissauer concludes that this immigration did not take place till well after the date when the river had taken its new course. Here, too, as elsewhere, we find the same entire revolution in the character of the Neolithic fauna as contrasted with the Palæolithic group of the Polish caves for example. Not a single representative remains. No reindeer bones even have been discovered on the Neolithic sites of the lands of the Lower Vistula, though the remains both of aurochs and of bison have been found.

Among the most interesting and characteristic objects that appear in association with the Neolithic deposits of the Lower Vistula are certain rude representations of human and animal figures cut out of amber. These remarkable productions, perforated as if for suspension, and engraved with fine lines, are more frequent to the east than to the west of the Vistula mouth ; but one of the most striking, a figure of a boar, ranked by Virchow amongst the best relics of the plastic art that have reached us from the Stone Age, was found in the neighbourhood of Danzig. These amber men and animals have been the object of a special study by Dr. Tischler, of Königsberg, whose researches into the prehistoric remains of East Prussia are the complement to those of Dr. Lissauer in the Western Province. In his admirable papers on the Stone Age in East Prussia, Dr. Tischler has shown that these figures are characteristic of an extensive East Baltic region; they have been found in the same shapes and with the same perforations, but cut out of bone and stalagmite instead of amber, in the Polish cave of Pod-kochanka ; and, what is still more remarkable, bone figures of analogous character have been discovered amidst the remains of a Neolithic station, described by the Russian explorer Inostranzeff, on the shores of the Lake of Ladoga. From these and other parallels, Dr. Tischler has been able to establish the existence of a distinct East Baltic Stone Province extending from the Oder to the Lake of Ladoga, and in all probability to the Onega shores, and including not only the provinces of East and West Prussia but the greater part of Poland. The relation of these northern "idols" to the clay figures of men and animals found in the Swiss lakedwellings, in the pile settlements of Laibach, and some of the prehistoric sites of Hungary and Transylvania, where one has been found of alabaster; and the relation again of these latter to the "Pallas" of Dr. Schliemann's Trojan excavations, or the rude "Carian" and Cypriote figures, suggest wide and far-reaching inquiries on which it is impossible here to embark.

Of the Bronze Age, pure and simple, there are very scanty remains in these East Baltic coast-lands; though there are sufficient examples, both of Hungarian and West Baltic forms, to show that before the close of the period in Central and North-Western Europe its arts were already taking root in this region. Dr. Lissauer's remarks on what he terms the "so-called Bronze Age," but which, in the greater part of our Continent at least, represents a very well defined stage of culture, reflect an attitude of mind not yet wholly extinct amongst German scholars. How far the Hallstatt culture can in this district be regarded as the immediate successor of that of Neolithic times is a 